\title{
Notes on the behavior of opossum (Didelphis sp.) in the wild in Usumacinta Canyon, México
}

\section{Notas sobre el comportamiento del tlacuache (Didelphis sp.) en vida silvestre en el Cañón del Usumacinta, México}

Fabiola Luna-Jiménez ${ }^{1}$, Francisco Botello ${ }^{1,2 *}$, Ángel Jiménez-Gómez ${ }^{3}$, Vicente Lopez-Moreno ${ }^{3}$, Juan Carlos Romero-Gil³ and Francisco Belmont-Buenrostro 3

\begin{abstract}
'Departamento de Zoología, Instituto de Biología, Universidad Nacional Autónoma de México. Circuito exterior s/n, C. P. 04510. Ciudad Universitaria, Ciudad de México, México. E-mail: lunalanie@ciencias.unam.mx (FL-J); francisco.botello@ib.unam.mx (FB). ${ }^{2}$ Departamento de Monitoreo Biológico, Conservación Biológica y Desarrollo Social, A. C. Calle Nueve No. 52, Int. 4, Colonia Espartaco, C. P. 04870. Ciudad de México, México.

${ }^{3}$ Área de Protección de Flora y Fauna Cañón del Usumacinta. Calle 26 No. 187, Colonia Luis Gómez Zepeda, C. P. 86901. Tenosique, Tabasco, México. E-mail: angel.jimenez@sinergiaplus.org (AJ-G); vicentelopezmoreno.bc@gmail.com (VL-M); jcromero@ conanp.gob.mx (JCR-G); fjavier.belmont@conanp.gob.mx (FB-B).

${ }^{*}$ Corresponding author
\end{abstract}

\begin{abstract}
Opossums are nocturnal, generalist, and opportunistic animals; however, little is known about their behavior in the wild, as most of the studies currently available have been conducted in captive individuals. This note reports the behavior of Didelphis sp. living in the wild as captured from camera trap photos and videos, highlighting the use of the tail to carry materials. The study was conducted in the Usumacinta Canyon, state of Tabasco, México. One camera trap was placed on 8 April 2020; it was left operating and set to capture photographs and videos. It was reviewed on 2 May 2020, identifying and sorting out the files corresponding to Didelphis sp. The behavior observed was identified, considering the time of capture and the sex of each individual identified. A total of 209 wildlife records were obtained, with 55 pertaining to Didelphis sp.; all were captured during the night. Five main types of behavior were identified, including carrying the young on the back and transporting plant material with the tail, mostly leaves of hackberry shrub (Celtis iguanaea) to build the nest. Most of the behaviors observed correspond to foraging; however, the behavior of transporting plant material with the tail, presumably to build the nest, is reported for the first time for México. Also, three nighttime peaks of activity are reported, as well as a female carrying the young in the marsupium and later on her back.
\end{abstract}

Key words: Behavior; camera trap; reproduction; time of activity; use of the tail.

Los tlacuaches son animales nocturnos, generalistas y oportunistas; no obstante, se conoce poco de su conducta en vida silvestre, ya que la mayoría de los estudios existentes son en cautiverio. En esta nota se reporta la conducta de Didelphis sp. en vida silvestre utilizando fotos y videos de una cámara trampa, resaltando el uso de la cola para transportar material. En el Cañón del Usumacinta, Estado de Tabasco, México, se colocó una cámara trampa el 8 de abril de 2020; se dejó funcionando y programada para tomar fotografías y videos. Se revisó el 2 de mayo del mismo año, identificando y separando los archivos correspondientes a Didelphis sp. Se identificó la conducta observada, considerando la hora y el sexo de cada individuo identificado. Se obtuvieron 209 registros de fauna silvestre, de los cuales 55 correspondieron a Didelphis sp., todos capturados durante la noche. Se identificaron 5 conductas principales dentro de las que destacan el tránsito con crías en el lomo y el transporte de material vegetal con la cola, probablemente hojas de garabato (Celtis iguanaea) para la construcción del nido. La mayoría de las conductas observadas corresponden al forrajeo; sin embargo, se reporta, por primera vez para México, el comportamiento de transportar material vegetal con la cola, presumiblemente para construir su nido. También, se reportan 3 picos de actividad durante la noche y se observa a una hembra con crías en el marsupio y posteriormente en su lomo.

Palabras clave: Cámara trampa; comportamiento; horario de actividad; reproducción; uso de cola.

(c) 2021 Asociación Mexicana de Mastozoología, www.mastozoologiamexicana.org

México is home to 12 species of marsupials (Didelphidae; Medina-Romero et al. 2012; Arcangeli et al. 2018), an ancestral group of great relevance for understanding the evolution of mammals. Two of these species are commonly known as opossum; these are very similar to each other. The southern opossum (Didelphis marsupialis) is found exclusively in the Mexican southeast, while the northern opossum (D. virginiana) is distributed throughout the Mexican territory, except the northwest region (Astua de Moraes et al. 2016; Pérez-Hernandez et al. 2016); therefore, these two species are sympatric over an extensive region.

Opossums are nocturnal, generalist, and opportunistic animals. They thrive in various habitats, even in areas with severe anthropogenic disturbance, and move across long distances in search of resources (McManus 1974; Kimble 1997; Oceguera-González and González-Romero 2008; Coronel-Arellano et al. 2021). Behavioral studies on these species are scarce and old; most of them were carried out 
in individuals observed in captivity or semi-captivity (Pray 1921; Layne 1951; Holmes 1991; Kimble 1997). Opossums have been described as mostly solitary animals with agonist interactions, except during mating and parental care; however, neutral and friendly interactions have also been reported (Holmes 1991; Kimble 1997).

The reproductive biology has been described in more detail for D. virginiana (e.g., McManus 1974) than for D. marsupialis. Gestation in D. virginiana lasts approximately 13 days; the offspring remain in the marsupium for 65 days, attached to a nipple. For this reason, although litters from 18 to 21 individuals have been observed, only 13 survive on average, matching the number of nipples in females. Similar data have been reported for $D$. marsupialis, except for the number of nipples, which are approximately 9, although litters of 10.7 offspring have been reported in captivity (Tyndale-Biscoe and MacKenzie 1976; DezonneMotta et al. 1983).

The breeding seasons, number of offspring per litter, and number of litters per year vary according to the geographic location. Only a single study has been carried out in México on the reproduction of these species in coffee plantations of central Veracruz (Oceguera-González and González-Romero 2008), reporting that opossums mate at the end of January and produce litters of 7 offspring in both species. A Venezuelan study (Cabello 2006) reported that precipitation determines the reproductive season (in the driest months) for both species, resulting in 3 litters of 3 to 9 offspring per year. In contrast, Tyndale-Biscoe and Mackenzie (1976) suggest that photoperiod is the factor regulating the onset of reproduction in D. marsupialis, with 2 large litters (6.5 offspring) or 3 small litters ( 4.5 offspring) per year.

Similar to other mammal species, opossums build nests in burrows or tree holes to protect their offspring from the environment and other animals. There are specific reports about this behavior for $D$. virginiana, but only one for $D$. marsupialis. The detailed behavior of how D. virginiana collects and carries materials to build a nest is as follows. First, it takes a piece of building material with the mouth, then uses the front legs to pass it under the abdomen and places it on the curved tail under its body; last, using the hind legs, it pushes the material to the curve of its tail, which is then rolled over to hold the material during the trip to the nesting site (Smith 1941; Layne 1951). This behavior seems to be the same in $D$. marsupialis, except that when the tail is full, females also use the marsupium to carry the material; the latter may be an exceptional report (Delgado-Velez et al. 2014).

The material used to build their nests is not clearly identified, and it may vary depending on the particular ecosystem they inhabit. For instance, a male opossum (D. virginiana) in captivity used dry leaves, feathers, and strips of newspaper (Layne 1951). In contrast, the only report on D. virginiana in the wild (Smith 1941) mentions the collection of dry leaves from the ground. In a separate report (the oldest mentioning this behavior), the researcher provided the material used (autumn leaves; Pray 1921). Also, a study on the gray short-tailed opossum (Monodelphis domestica) has reported that females build nests of better quality than males and that temperature influences nest construction (Fadem et al. 1986).

This study reports very interesting data on the reproduction and behavior of Didelphis sp. in the wild, obtained from photographs and videos captured during the participatory monitoring program of the Usumacinta Canyon Flora and Fauna Protection Area (APFFCU, for its name in Spanish), which aims to document the species diversity of wild terrestrial vertebrates.

The APFFCU is located in the municipality of Tenosique, state of Tabasco, México. It is bordered by the state of Chiapas, México, to the east and by Guatemala to the south, where the Sierra del Lacandón National Park is located. It comprises 46,128.49 ha, including human settlements, water bodies, induced grasslands, crops, high evergreen rainforest, low thorny sub-deciduous rainforest, high evergreen rainforest with secondary vegetation, and tular vegetation (SEMARNAT 2015).

The daily activities of APFFCU staff include a participatory monitoring program with committees from different localities within the protected area. As part of this program, in the Niños Héroes de Chapultepec ejido on 8 April 2020, the community brigadier Vicente López Moreno placed one Bushnell Model $119975 \mathrm{C} 12$ megapixels (mp) camera trap at geographic coordinates $17^{\circ} 16^{\prime} 18.4^{\prime \prime} \mathrm{N}, 91^{\circ} 25^{\prime} 10.2^{\prime \prime} \mathrm{W}$ (Figure 1) and $564 \mathrm{~m}$, corresponding to a high evergreen rainforest. The camera trap was set to capture one photograph followed by one 15-second video, with a 30-second activation interval in case of motion detection; it was left operating until 2 May 2020, for a total of 25 camera trap days. A sardine can was used as bait only once at the start of the camera trapping period.

The photographs and videos captured were reviewed, sorting out all the captures corresponding to Didelphis sp. Didelphis virginiana and D. marsupialis were differentiated based on the tail coloration: less than half of the tail is black in the northern opossum (D. virginiana) while more than half is black in the southern opossum (D. marsupialis), according to Aranda-Sánchez (2012). However, we considered that this character alone is insufficient for reliable identification.

The number of photographs and videos was counted, as well as the effective capture time, defined as the period of time that an individual is observed within the 15-second total duration of each video. The time of capture was recorded for all photographs; the sex (female or male) and life stage (adult or young) of each specimen were noted, and an identification key was assigned in each case (Table 1). Whenever possible, the sex was determined from the visualization of the scrotum in males and the marsupium or by carrying offspring, either in the marsupium or on the back, in females. 

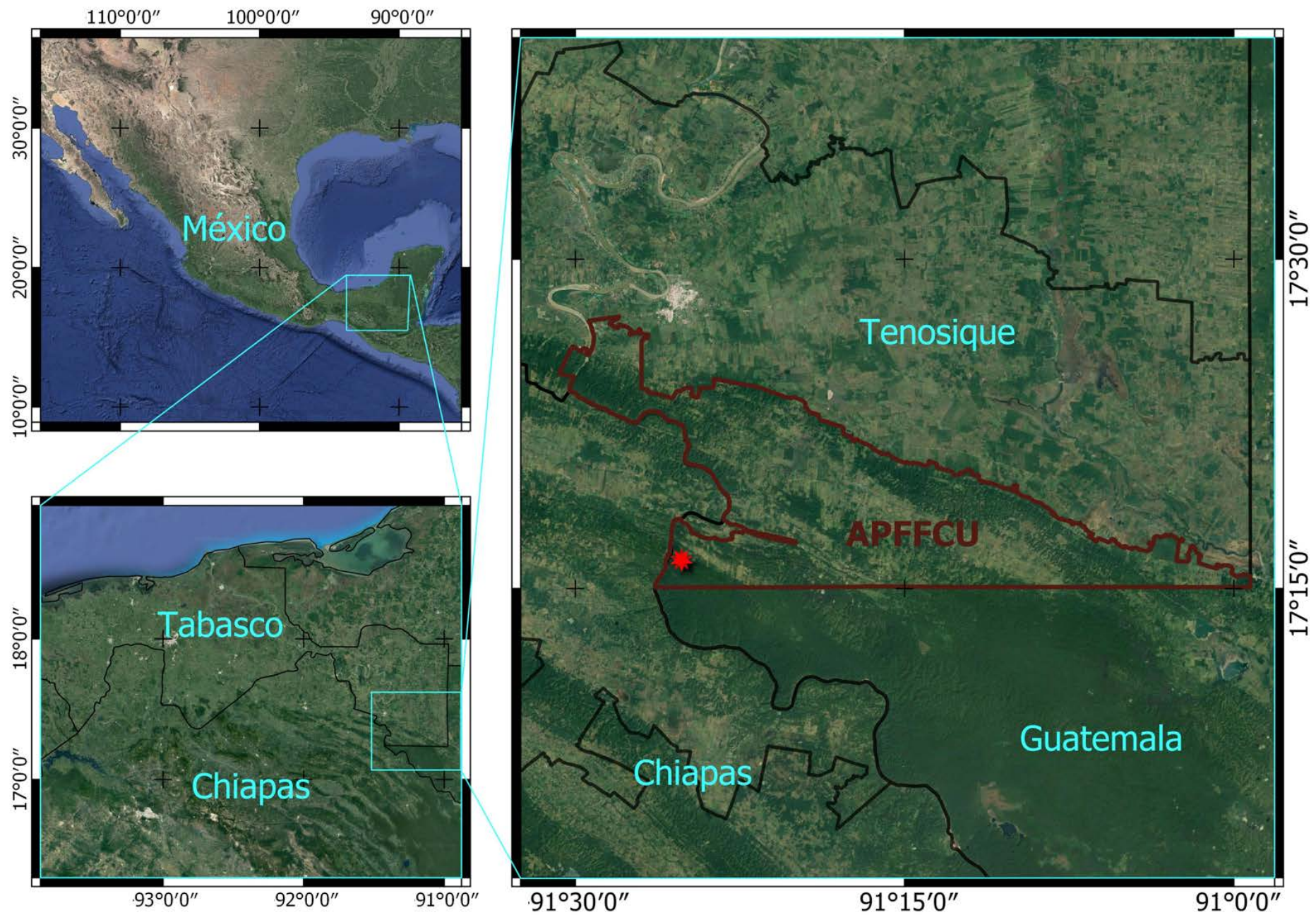

$91^{\circ} 30^{\prime} 0^{\prime \prime}$

$91^{\circ} 0^{\prime} 0^{\prime \prime}$

Figure 1. Geographic location of the camera trap (red star) placed in the Usumacinta Canyon Flora and Fauna Protection Area (APFFCU), Tenosique, Tabasco, México.

Aspects such as size, sex, color patterns, and tail shape were considered to characterize each individual, considering the latter two aspects as natural marks that uniquely identify each individual, similar to the identification approach applied for other species such as the ocelote (Leopardus pardalis; Gómez-Ramírez et al. 2017), leopard (Panthera pardus; Webb et al. 2020), and chimpanzee (Pongo spp.; Spehar et al. 2015). The observed behaviors were classified as described in McManus (1974), Holmes (1991), and Kimble (1997).

A total of 209 wildlife records were captured, with 55 pertaining to Didelphis sp.: 45 photographs with their respective 15-second video, 5 photographs with no video, and 5 videos with no previous photograph. All captures where the complete tail was observed corresponded to $D$. virginiana, including all the individuals identified. In total, $12 \mathrm{~min} 30 \mathrm{~s}$ of video was filmed, of which $9 \mathrm{~min} 28 \mathrm{~s}$ was the effective capture time during which the animal is observed. All records were captured during the night, with peaks of activity from 01:00 to $02: 00 \mathrm{hr}, 04: 00$ to $06: 00 \mathrm{hr}$, and 19:00 to $21: 00 \mathrm{hr}$, with less activity from 21:00 to 24:00 hr (Figure 2).
A total of 56 captures of opossum were obtained; 2 individuals were observed in a single video, and 5 different individuals were identified. 43 records correspond to female opossum, 5 to male opossum, 1 to a young, and 7 to individuals that could not be identified or sexed (Table 1). One female, Th1, was observed with offspring: first, in the marsupium (Figure 3a); later, on her back (Figure 3b). In two captures of Th1, only 5 offspring were observed on the back; in a third capture, 7 offspring were recorded.

Five different types of behavior were identified (Table 2). (1) Grooming: the animal licked its front legs or it cleaned its face with a front leg or it scraped its head with a hind leg or all of the above. (2) Search: the opossum walked slowly, sniffing with the snout directed to the substrate. (3) Substrate manipulation: the animal was removing the substrate with its snout slightly buried in the surface (sometimes with the help of the front legs) and possibly feeding. (4) Passing: the opossum only passed in front of the camera either running, walking, carrying material in its tail or carrying offspring on its back (Figure 3b, 3c, 3d). (5) Arboreal behaviors: climbing up a tree, i.e., the animal was observed climbing up in a vertical position, holding the trunk with 


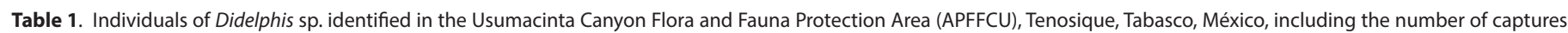
and duration of capture.

\begin{tabular}{|c|c|c|c|c|}
\hline Individuals identified & No. of captures & Percentage of captures (\%) & Duration of capture time $(s)^{*}$ & Percentage of duration of capture (\%) \\
\hline Females** & 43 & 76.79 & 496 & 86.56 \\
\hline Th1 & 33 & 58.93 & 399 & 69.63 \\
\hline Offspring on the back & 3 & 5.36 & 23 & 4.01 \\
\hline Offspring in the marsupium & 16 & 28.57 & 203 & 35.43 \\
\hline Th2 & 9 & 16.07 & 82 & 14.31 \\
\hline Males & 5 & 8.93 & 50 & 8.73 \\
\hline $\operatorname{Tm} 1$ & 1 & 1.79 & 15 & 2.62 \\
\hline $\operatorname{Tm} 2$ & 4 & 7.14 & 35 & 6.11 \\
\hline Juveniles & 1 & 1.79 & 15 & 2.62 \\
\hline $\mathrm{Tj} 1$ & 1 & 1.79 & 15 & 2.62 \\
\hline $\mathrm{NI}$ & 7 & 12.50 & 12 & 2.09 \\
\hline
\end{tabular}

*Includes photograph-only records ( 1 photo $=1$ second)

**Includes one record where the individual was not identified.

the digits of the four legs (Figure 3e), and climbing off a tree, when the opossum was descending toward the substrate in an almost vertical position, with its tail around the trunk (Figure $3 \mathrm{f}$ ).

Unfortunately, this study did neither visualize nests nor clearly identify the leaves transported. However, based on the shape and coloration of leaves, the occurrence at the study site, and the local knowledge of one of the coauthors (VL-M) living in the locality, it is suggested that the leaves transported could be from the hackberry shrub, Celtis iguanaea.
We decided to identify the opossums observed as Didelphis sp. only, since two very similar species of this genus co-inhabit the APFFCU, D. virginiana and D. marsupialis (SEMARNAT 2015). Although there are morphological features that are unique to each of them, such as those described in Aranda-Sánchez (2012), these were difficult to observe clearly in the black-and-white photographs and videos captured. For the above, we consider that the taxonomic identification based solely on the coloration of the tail is not sufficiently robust. Nonetheless, the individuals captured likely correspond to $D$. virginiana.

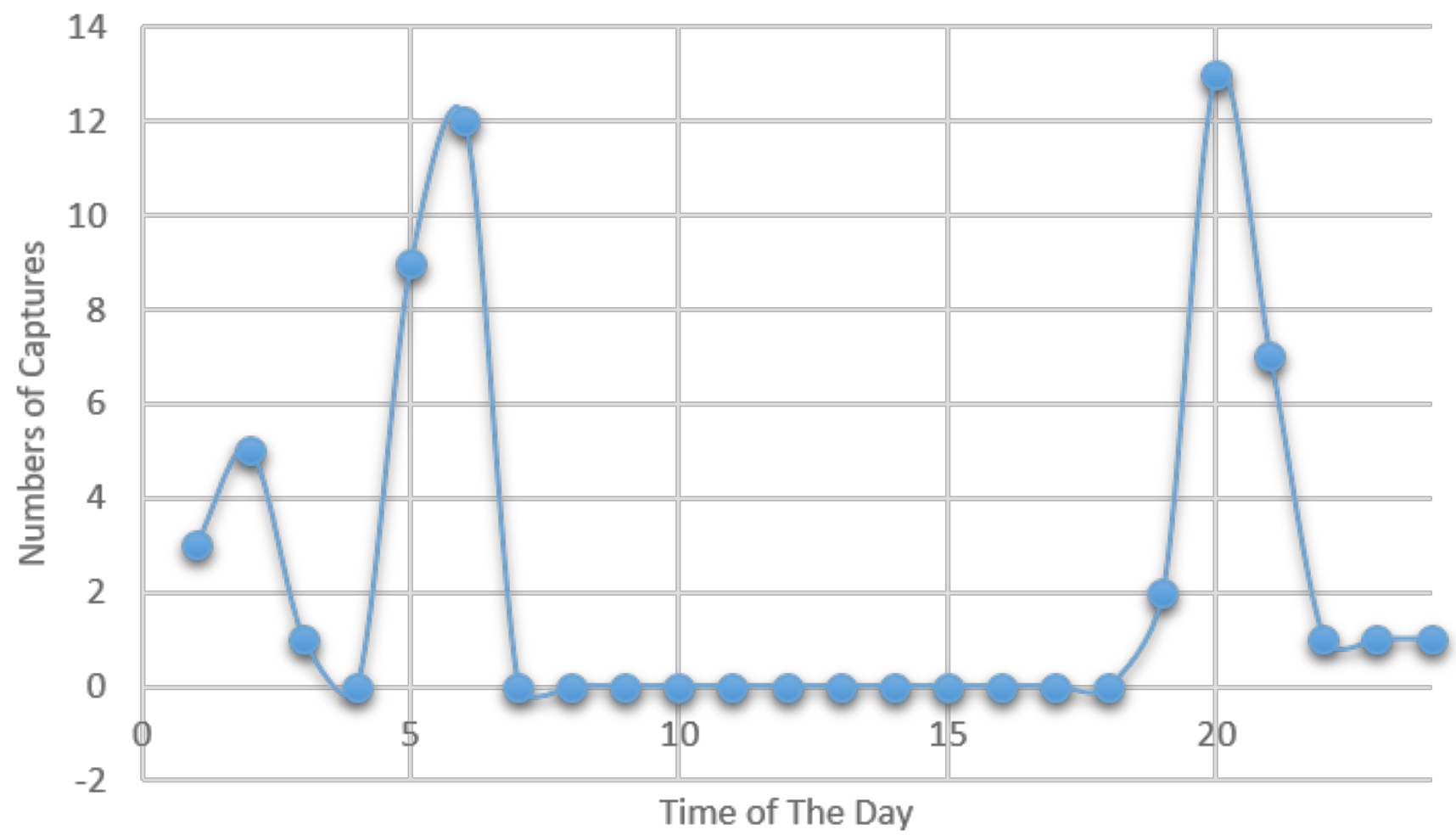


México 


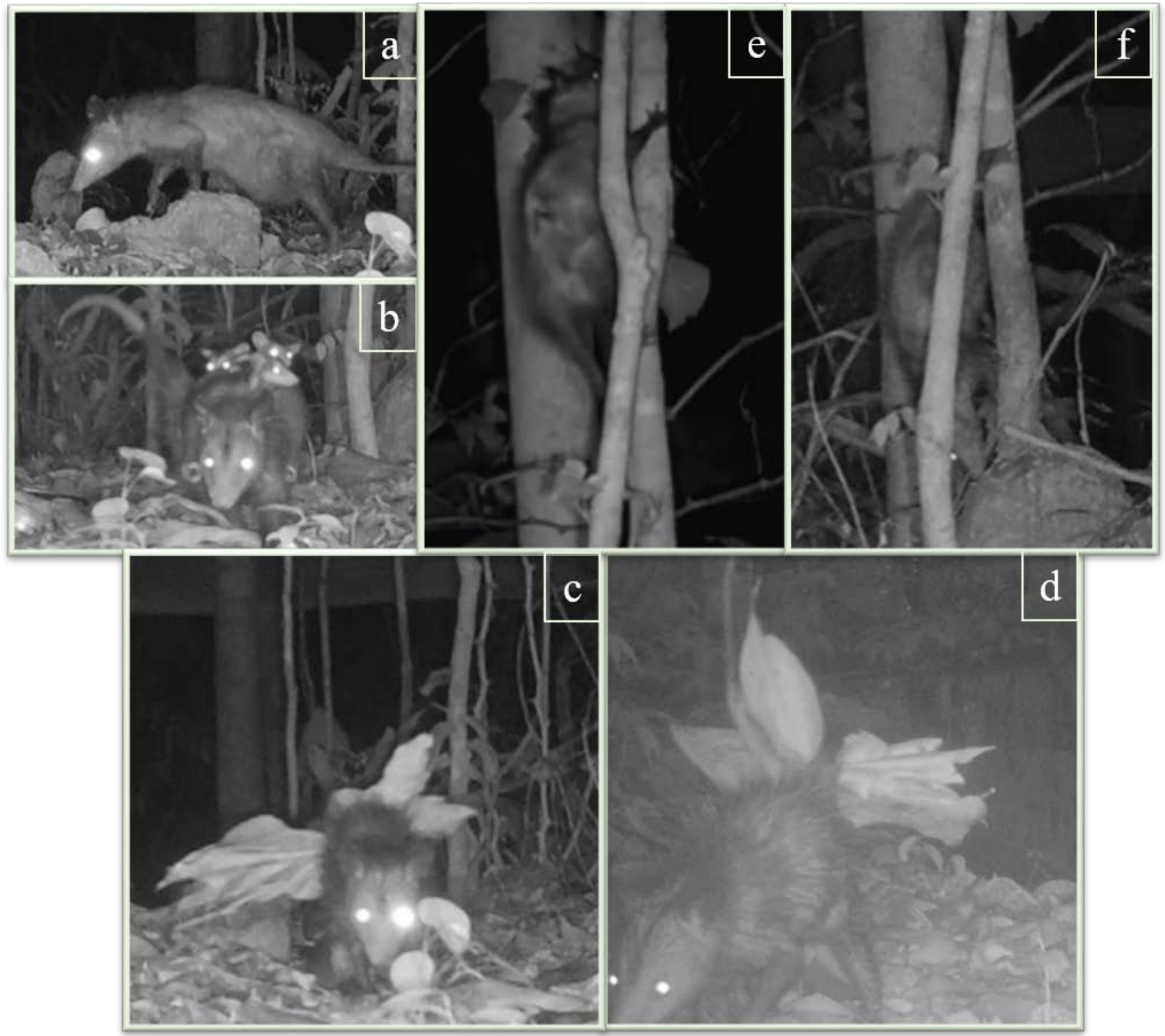

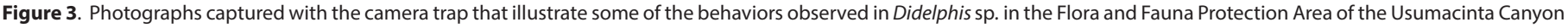

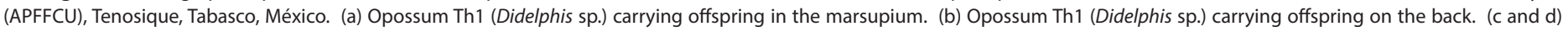
Opossum Th2 (Didelphis sp.) carrying material with its tail. (e) Opossum Th1 (Didelphis sp.) climbing up a tree. (f) Opossum Th1 (Didelphis sp.) climbing down a tree.

This study reports that in APFFCU, Didelphis sp. displays 3 peaks of activity in April-May (Figure 2): 01:00-02:00 hr, 04:00-06:00 hr, and 19:00-21:00 hr. This differs from the activity described by McManus (1971) for D. virginiana, who reported a peak from 21:00 to 02:00 hr in spring in semi-captive specimens in Ithaca, New York, based on direct observations. This discrepancy may be due to methodological or environmental differences, since a separate study of $D$. virginiana in the wild over nearly a year using a methodology similar to the one in the present study (camera traps) and in a study site closer to ours (México City, México) reported two peaks of activity: one around 04:00 hr and another at about 22:00 hr (Coronel-Arellano et al. 2021), which are consistent with the findings reported in this note. Although the studies mentioned coincide in describing nocturnal habits, we suggest that the peaks of activity vary according to the latitude and ecosystem because temperature and lighting are different.

Most of our captures were of females, especially Th1 (58.93\%, Table 1). Th1 was observed with their offspring from the time they were in the marsupium to the moment when they were carried on the back (Figure $3 a, 3 b$ ); the young observed at the end of the camera trapping period belongs to this litter, although there is no assurance that $\mathrm{Tj} 1$ is an offspring of Th1. The number of offspring observed in this litter (7) is consistent with the litter size reported in the literature (McManus 1974; Tyndale-Biscoe and MacKenzie 1976; Cabello 2006; Ocequera-González and González- 


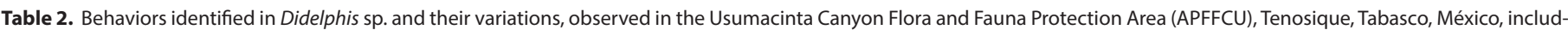
ing the number of sightings and duration of capture.

\begin{tabular}{lcccc}
\hline \multicolumn{1}{c}{ Behavior identified } & No. of sightings & Percentage of sightings (\%) & Duration of capture (s) & Percentage of duration of capture (\%) \\
\hline Grooming & 3 & 4.92 & 23 & 4.05 \\
Search & 32 & 52.46 & 372 & 65.49 \\
Substrate manipulation & 10 & 16.39 & 61 & 16.02 \\
Passing through & 11 & 18.03 & 1 & 11.62 \\
$\quad$ Running & 1 & 1.64 & 65 & 0.18 \\
Walking & 10 & 16.39 & 40 & 11.44 \\
$\quad$ Alone & 5 & 8.20 & 2 & 23 \\
$\quad$ Carrying material & 2 & 3.28 & 16 & 0.35 \\
$\quad$ Carrying offspring & 3 & 4.92 & 10 & 4.04 \\
Arboreal behaviors & 5 & 8.20 & 6 & 1.76 \\
$\quad$ Climbing up a tree & 3 & 4.92 & 3.28 & 1.06 \\
$\quad$ Climbing off a tree & 2 & &
\end{tabular}

$\mathrm{s}=$ seconds

Romero 2008); however, we first captured 5 young and then 7. The latter could be due to the position of the offspring on the back, which prevented observing all of them; alternatively, they may have not left the marsupium when the images were captured.

Most of the behaviors observed are consistent with foraging: search (65.49 \%) and substrate manipulation (16.02 \%, Table 2). Didelphis sp. is considered a generalist and opportunistic genus; however, there are no studies focused on its foraging behavior, particularly in the wild. Although the passing behavior occurred only in $11.62 \%$ of captures, it provided information that was last reported by Hopkins (1977) for D. virginiana and by Delgado-Velez et al. (2014) for D. marsupialis. Finally, arboreal behaviors (2.82\%), i.e., climbing up (1.76\%) and down a tree (1.06\%), where the less observed behaviors and offer an indication about these habits in this species and its locomotion when climbing.

In captures where an opossum is observed climbing up or off a tree (Figure 3e, 3f), the behavior is very similar to the one observed in Caluromys philander (Dalloz et al. 2012), especially as regards the use of the tail. When climbing up a tree, the tail is stretched or moved to a position relative to the body so as to maintain balance. In contrast, when an individual is climbing down a tree, the tail is wrapped around the trunk for quick anchoring, if needed; this observation is consistent with Dalloz et al. (2012).

Two images captured a female of Didelphis sp. (Th2) using the tail to carry material to its nest (Figure 3c, 3d; Table 2); this is the first report of this behavior for México. This behavior has also been reported in other didelphids: Monodelphis domestica (Unger 1982; Fadem et al. 1986), M. dimidiata (González and Claramunt 2000), C. philander (Dalloz et al. 2012), and Metachirus nudicaudatus (DelgadoVelez et al. 2014); and in males of $D$. virginiana (Layne 1951; Hopkins 1977) and individuals of D. marsupialis (Delgado-
Velez et al. 2014). Nests of Marmosa canescens (Ceballos 1990) have also been reported and described, but the way they carry the material for nest construction is unknown.

Whether the use of the tail to carry material is a learned or an innate behavior is currently unknown; however, this behavior has been reported in young of $D$. virginiana of 88 to 97 days of age with no apparent learning involved (Hopkins 1977). The behavior observed in this study and described above, which has also been reported for other species of the family Didelphidae, may be an ancestral trait typical of didelphids. Further studies are needed, which may be challenging as these organisms are rare and difficult to observe in the wild.

Although in $M$. domestica both males and females are known to build nests, with females being better at it (Fadem et al. 1986), it is not clear whether the same holds true for $D$. virginiana or D. marsupialis. Unfortunately, nests of Didelphis sp. were not observed in this study, although they may be similar to those described for other didelphids. The nests described are spherical or globe-shaped (Unger 1982; Loretto et al. 2005). The nests of M. domestica have three levels: the first is the base, the second is an inner chamber with thick walls, and the third forms the vaulted ceiling (Unger 1982).

In the present study, the leaves transported could not be clearly identified; however, they probably correspond to the hackberry shrub (Celtis iguanaea). The material used by $D$. virginiana and $D$. marsupialis for the construction of their nests consists mainly of dry leaves according to studies conducted in the wild (Smith 1941; Dalloz et al. 2012; Delgado-Velez et al. 2014), although herbs and plant fibers (Ceballos 1990) or pieces of roots have also been reported (Loretto et al. 2005) for other didelphids. In studies under captivity, the material for nest building has been provided, being mostly paper strips (Hopkins 1977; Unger 1982; 
Fadem et al. 1986; González and Claramunt 2000), and in one case, dried leaves, feathers, and pieces of newspaper (Layne 1951). An experimental study (Unger 1982) suggests that $M$. domestica chooses any materials suitable for construction; however, no other experimental studies explored how other didelphids choose the materials they use for nest building.

The nest-building site varies according to whether nests are on trees, semi-arboreal, or built on the ground, as nests can be found in holes of trees and shrubs, between tree roots, or under the leaf litter layer (Ceballos 1990; Dalloz et al. 2012). In addition, opossums have been observed to change their nesting sites within two months (Loretto et al. 2005). Didelphis sp. is mostly terrestrial, but this does not exclude all the potential nesting sites mentioned above.

Nests are assumed to provide protection from environmental conditions and predation; however, not many studies have evaluated this assumption. Unger (1982) reported that $M$. domestica built nests when days were sunny, suggesting that nests are used to get protection from warm weather. Conversely, Fadem et al. (1986) evaluated the effect of temperature, finding that lower ambient temperatures are related to nests built using more material, suggesting that these nests protect from cold weather and contribute to thermoregulation.

In our opinion, further studies on $D$. virginiana and $D$. marsupialis in the wild are needed, for which camera traps are very useful. These studies should include a detailed description of the nests built in the wild and investigate how opposums choose the materials to build their nests, how and where nests are built, whether there are factors affecting nest construction or prompting the relocation of nesting sites, or whether this occurs regularly. These studies will enable us to understand the importance of nesting and its role in reproduction and survival in these species.

Although opossums of the genus Didelphis are common, this research reports for the first time for México their behavior regarding the transport of plant material with the tail, presumably to build a nest, and the presence of several individuals at the same site. In addition, this study confirmed the nocturnal habits of Didelphis sp., recording 3 peaks of activity during April and May in the APFFCU area. Other behaviors of opossums, such as females carrying their young in the marsupium and on the back, are also reported.

\section{Acknowledgements}

To APFFCU community brigades, who are dedicated to monitoring activities. Thanks also to the Direction of the Cañón del Usumacinta Natural Protected Area (ANP) of the National Commission of Natural Protected Areas (CONANP, in Spanish), which since its creation have built the capacities of the ANP inhabitants, and for the efficient follow-up of biological monitoring. We wish to thank two anonymous reviewers whose valuable comments and suggestions contributed to the preparation of this note. And we thank M. E. Sánchez-Salazar for translating the manuscript into English.

\section{Literature cited}

Aranda-Sánchez, J. M. 2012. Manual para el rastreo de mamíferos silvestres en México. Comisión Nacional para el Conocimiento y Uso de la Biodiversidad (CONABIO), No. 599 A7. México City, México.

Arcangel, J., J. E. Light, and F. A. Cervantes. 2018. Molecular and morphological evidence of the diversification in the gray mouse opossum, Tlacuatzin canescens (Didelphimorphia), with description of a new species. Journal of Mammalogy 99:138-158.

Astua de Moraes, D., D. Lew, L. P. Costa, and R. Pérez-Hernandez. 2016. Didelphis marsupialis. In: IUCN 2016. The IUCN Red List of Threatened Species. Version 2016. www.iucnredlist.org. Accessed February 24, 2021.

CABelLo, D. R. 2006. Reproduction of Didelphis marsupialis (Didelphimorphia: Didelphidae) in the Venezuelan Andes. Acta Theriologica 51:427-433.

Ceballos, G. 1990. Comparative natural history of small mammals from tropical forests in western Mexico. Journal of Mammalogy 71:263-266.

Coronel-Arellano, H., M. Rocha-Ortega, F. Gual-Sill, E. Martínez-Meyer, A. K. Ramos-Rendón, M. González-Negrete, G. Gil-Alarcón, and L. Zambrano. 2021. Raining feral cats and dogs? Implications for the conservation of medium-sized wild mammals in an urban protected area. Urban Ecosystems 24:83-94.

Dalloz, M. F., D. Loretto, B. Papi, P. Cobra, and M. V. Vieira. 2012. Positional behaviour and tail use by the bare-tailed woolly opossum Caluromys philander (Didelphimorphia, Didelphidae). Mammalian Biology 77:307-313.

Delgado-Velez., C. A., A. Arias-Alzate, S. Aristizábal-Arango, AND J. D. SÁnchez-Londoño. 2014. Uso de la cola y el marsupio en Didelphis marsupialis y Metachirus nidicaudatus (Didelphimorphia: Didelphidae) para transportar material de anidación. Mastozoología Neotropical 21:129-134.

Dezonne-Motta, M. F., J. C. de Araujo Carreira, and A. M. Ramos Franco. 1983. A note on reproduction of Didelphis marsupialis in captivity. Memorias do Instituto Oswaldo Cruz 78:507-509.

Fadem, B. H., D. B. Kraus, and R. H. Sheffet. 1986. Nest-building in gray short tailed opossums: temperature effects and sex differences. Physiology and Behavior 36:667-670.

Gómez-Ramírez, M. Á., C. E. Gutiérrez-González, and C. A. López-González. 2017. Ocelots thrive in a non-typical habitat of northwestern Mexico. Endangered Species Research 32:471-478.

González, E. M., and S. Claramunt. 2000. Behaviors of captive short-tailed opossums, Monodelphis dimiata (Wagner, 1847) (Didelphimorphia, Didelphidae). Mammalia 64:271-285.

Holmes, D. J. 1991. Social behavior in captive Virginia opossums, Didelphis virginiana. Journal of Mammalogy 72:402-410.

Hopkins, D. 1977. Nest-building behavior in the immature Virginia opossum (Didelphis virginiana). Mammalia 41:361-362.

KımвLE, D. P. 1997. Didelphid Behavior. Neuroscience and Biobehavioral Reviews 21:361-369.

LAYNE, J. N. 1951. The use of the tail by an opossum. Journal of Mammalogy 32:464-465. 
Loretto, D., E. Ramalho, and M. V. Vieira. 2005. Defense behaviour and nest architecture of Metachirus nudicaudatus Desmarest, 1817 (Marsupialia, Didelphidae). Mammalia 69:417-419.

McManus, J. J. 1971. Activity of captive Didelphis marsupialis. Journal of Mammalogy 52:846-848.

McManus, J. J. 1974. Didelphis virginiana. Mammalian Species 40:1-6.

Medina-Romero, M., I. Goyenechea, and J. Castillo-Cerón. 2012. Phylogenetic measures applied to the conservation of Mexican marsupials. Revista Mexicana de Biodiversidad 83:1216-1220.

Oceguera-González, A., And A. González-Romero. 2008. Hábitos alimentarios y reproducción de dos especies de tlacuache en cafetales del centro de Veracruz, México. Pp. 295-309 in Avances en el Estudio de los Mamíferos de México (Lorenzo, C., E. Espinoza, and J. Ortega, eds.). Publicaciones Especiales Vol. Il, Asociación Mexicana de Mastozoología, A. C. Chiapas, México.

Pérez-Hernandez, R., D. Lew, And S. Solari. 2016. Didelphis virginiana. In: IUCN 2016. The IUCN Red List of Threatened Species. Version 2016. www.iucnredlist.org. Accessed February 24, 2021.

PraY, L. 1921. Opossum carries leaves with its tail. Journal of Mammalogy 2:109-110.

Secretaría del Medio Ambiente y Recursos Naturales (SEMARNAT). 2015. Programa de manejo Área de Protección de Flora y Fauna Cañón del Usumacinta. Secretaría del Medio Ambiente y Recursos Naturales, Comisión Nacional de Áreas Naturales Protegidas. México City, México.

Sмiтн, L. 1941. An observation on the nest-building behavior of the opossum. Journal of Mammalogy 22:201-202.

Spehar, S. N., B. Loken, Y. Rayadin, And J. A. Royle. 2015. Comparing spatial capture-recapture modeling and nest count methods to estimate orangutan densities in the Wehea Forest, East Kalimantan, Indonesia. Biological Conservation 191:185-193.

Tyndale-Biscoe, C. H., And R. B. MacKenzie. 1976. Reproduction in Didelphis marsupialis and D. albiventris in Colombia. Journal of Mammalogy 57:249-265.

UNGER, K. L. 1982. Nest-building behavior of the brazilian bare-tailed Opossum, Monodelphis domestica. Journal of Mammalogy 63:160-162.

Webb, E. L., Y. R. Choo, E. P. Kudavidanage, T. R. Amarasinghe, U. G. S. I. Bandara, W. A. C. L. Wanninayaka, P. Ravindrakumar, T. S. Nimalrathna, S. H. Liang, and M. A. H. Chua. 2020. Leopard activity patterns in a small montane protected area highlight the need for integrated, collaborative landscape conservation. Global Ecology and Conservation 23:e01182. 